\title{
Wastewater treatment plants as a source of microbial pathogens in receiving watersheds
}

\author{
Anthony I. Okoh*, Emmanuel E. Odjadjare, Etinosa O. Igbinosa and Augustina N. Osode \\ Applied and Environmental Microbiology Research Group (AEMREG), Department of Biochemistry and Microbiology, \\ University of Fort Hare, Private Bag X1314, Alice 5700, South Africa.
}

Accepted 13 November, 2007

\begin{abstract}
Wastewater treatment facilities have become sin quo non in ensuring the discharges of high quality wastewater effluents into receiving water bodies and consequence, a healthier environment. Due to massive worldwide increases in human population, water has been predicted to become one of the scarcest resources in the $21^{\text {st }}$ century, and despite large advances in water and wastewater treatments, waterborne diseases still pose a major threat to public health worldwide. Several questions have been raised on the capacity of current wastewater treatment regimes to remove pathogens from wastewater with many waterborne diseases linked to supposedly treated water supplies. One of the major gaps in the knowledge of pathogenic microorganisms in wastewater is the lack of a thorough understanding of the survival and persistence of the different microbial types in different conditions and environments. This therefore brings to the fore the need for a thorough research into the movement and behavior of these microorganisms in wastewaters. In this review paper we give an overview of wastewater treatment practices with particular emphasis on the removal of microbial pathogens.
\end{abstract}

Key words: Wastewater, treatment plants, microbial pathogens, watershed.

\section{INTRODUCTION}

It has been predicted that, due to massive worldwide increases in the human population, water will become one of the scarcest resources in the $21^{\text {st }}$ century (Day, 1996). As human numbers increase, greater strains will be placed on available resources and pose even greater threat to environmental sources. A report by the Secretary-General of the United Nations Commission on Sustainable Development (UNCSD, 1997) concluded that there is no sustainability in the current uses of fresh water by either developing or developed nations, and that worldwide, water usage has been growing at more than three times the world's population increase, consequently leading to widespread public health problems, limiting economic and agricultural development and adversely affecting a wide range of ecosystems.

Much of the wastes of civilization enter water bodies through the discharge of waterborne waste from domestic, industrial and non-point sources carrying unwanted

"Corresponding author. E-mail: aokoh@ufh.ac.za. and unrecovered substances (Welch, 1992). Although the collection of wastewater dates back to ancient times, its treatment is a relatively recent develop-ment dating from the late 1800s and early 1900s (Chow et al., 1972). Modern knowledge of the need for sanitation and treatment of polluted waters however, started with the frequently cited case of John Snow in 1855, in which he proved that a cholera outbreak in London was due to sewage contaminated water obtained from the Thames River (Cooper, 2001).

Wastewater treatment practices vary from country to country across the globe. In developed nations, treatment and discharge systems can sharply differ between countries and between rural and urban users, with respect to urban high income and urban low-income users (Doorn et al., 2006). The authors further reported that the most common wastewater treatment methods in developed countries are centralized aerobic wastewater treatment plants and lagoons for both domestic and industrial wastewater. Domestic wastewater may also be treated in on-site septic systems involving wastewater from one or several households consisting of an anaer- 
obic underground tank and a drainage field for the treatment of effluent from the tank (UNEP, 2002). However, there are still communities without wastewater treatment facilities in developed countries, and in some cases existing infrastructure is faltering; and even in areas with a high degree of wastewater treatment, pathogens and some chemicals, many with unknown ecological consequences, may still be released into the environment (LeChevallier and Au, 2004; Paillard et al., 2005).

The degrees of wastewater treatment vary in most developing countries. Domestic wastewater may be treated in centralized plants, pit latrines, septic systems or disposed of in unmanaged lagoons or waterways, via open or closed sewers (UNEP, 2002). In some cases industrial wastewater is discharged directly into bodies of water, while major industrial facilities may have comprehensive in-plant treatment (Carter et al., 1999; Doorn et al., 2006). In many developing countries the bulk of domestic and industrial wastewater is discharged without any treatment or after primary treatment only. In Latin America about $15 \%$ of collected wastewater passes through treatment plants (with varying levels of actual treatment). In Venezuela, $97 \%$ of the country's sewage is discharged raw into the environment (Caribbean Environment Programme Technical Report \#40 1998). Even a highly industrialized country such as China discharges about 55 percent of all sewage without treatment of any kind (The People's Daily, Friday, November 30, 2001). In a relatively developed Middle Eastern country such as Iran, the majority of Tehran's population has totally untreated sewage injected into the city's groundwater (Tajrishy and Abrishamchi, 2005). In South Africa where some level of wastewater treatment is observed, Momba et al. (2006) reported the poor operational state and inadequate maintenance of most of the municipalities' sewage treatment works as leading to the pollution of various water bodies thereby posing very serious health and socio-economic threats to the dependants of such water bodies. Most of sub-Saharan Africa is without wastewater treatment (Sci-Tech. Encyclopaedia, 2007).

Despite advances in water and wastewater treatments, waterborne diseases still pose a major threat to public health worldwide (Zhou and Smith, 2002). Many of these infections occur in developing countries which have lower levels of sanitation, problems associated with low socioeconomic conditions, and less public health awareness than in developed countries (Toze, 1997; Elimelech, 2006). The health risks for the public from wastewater can come from microbial pathogens, toxic chemicals, and heavy metals. This review addresses the common practices of wastewater treatment with emphasis on the consequences of inadequate treatment regimes resulting in the pollution of the receiving aquatic milieu with micro- bial pathogens as is common in developing countries.

\section{TYPES OF WASTEWATER TREATMENT FACILITIES}

\section{Oxidation ponds}

Oxidation ponds are effective, low-cost, and simple technology for reducing the BOD of a wastewater before it is discharged to an aquatic ecosystem. It consists of ring or oval shaped channel equipped with mechanical aeration devices. Screened wastewater entering the pond, is aerated by mechanical devices which circulates at about 0.25 to $0.35 \mathrm{~ms}^{-1}$. Oxidation ponds typically operate in an extended aeration mode with long detention and solids retention times (Von Sperling and De Lemos, 2005).

\section{Anaerobic ponds}

Anaerobic pond as a wastewater treatment facility is a biological process ideally suited for the pre-treatment of high-strength wastewaters. The anaerobic process utilizes naturally-occurring bacteria to break down biodegradable material in wastewater. Because the bacteria are anaerobic they do not require oxygen like the organisms in an aerobic process. Used prior to aerobic treatment, an anaerobic system can be very effective and economical for removing high concentrations of $\mathrm{BOD}_{5}$ and COD (Dewil et al., 2006). The pond is relatively deep, 3 to $4 \mathrm{~m}$, as this concentrates the biological action and reduces heat loss. Anaerobic ponds contain an organic loading that is very high relative to the amount of oxygen entering the pond. This maintains anaerobic conditions to the pond surface. Anaerobic bacteria break down the organic matter in the effluent, releasing methane and carbon dioxide. Sludge is deposited at the bottom and a crust may form on the surface (Doorn et al., 2006). They work extremely well in warm climates; a properly designed and not significantly underloaded anaerobic pond will achieve around $60 \%$ BOD removal at $20^{\circ} \mathrm{C}$ and as much as $75 \%$ at $25^{\circ} \mathrm{C}$.

\section{Aerobic ponds}

This is another wastewater treatment facility which contains bacteria and algae in suspension and maintains aerobic conditions throughout its depth. There are two types of aerobic ponds: shallow ponds and aerated ponds (Vijayaraghavan et al., 2007).

\section{Shallow pond}

Shallow aerobic ponds obtain their dissolved oxygen via two processes: oxygen transfer between air and water 
surface, and oxygen produced by photosynthetic algae. Although the efficiency of soluble biochemical oxygen demand removal can be as high as $95 \%$, the pond effluent will contain a large amount of algae which will contribute to the measured total biochemical oxygen demand of the effluent. To achieve removal of both soluble and insoluble biochemical oxygen demand, the suspended algae and microorganisms have to be separated from the pond effluent (George and Andrew, 2003).

\section{Aerated ponds}

An aerated pond is similar to an oxidation pond except that it is deeper and mechanical aeration devices are used to transfer oxygen into the deeper portions of the pond. The aeration device also facilitates a proper mix of the wastewater and bacteria. The main advantage of the aerated pond is that they require less area than oxidation ponds. The disadvantage is that the mechanical aeration devices require maintenance and use energy (Craggs et al., 2003; Elimelech, 2006).

\section{Facultative ponds}

Facultative ponds are generally aerobic; however, these ponds do operate in a facultative manner and have an anaerobic zone. The depth of natural-aeration facultative ponds (usually 1.0 to 1.5 ) $\mathrm{m}$ is too deep for oxygen to penetrate to the bottom of the pond, and an anaerobic zone develops there. Solids from the incoming waste settle into the anaerobic sludge near the bottom of the pond and degrade anaerobically releasing soluble degradable organic material and nutrients which diffuse upwards in the pond (Sharman, 2004). Near the top of the pond oxygen is supplied by algal photosynthesis and to a limited extent by diffusion from the air. Dissolved oxygen is present to only a few centimetres depth at night, but diffuses deeper during daylight (Tchobanoglous and Angelaki, 1996; Al-Sa'ed, 2001). Thus there exists a fully aerobic zone at the top of the pond, and between this and the anaerobic zone at the bottom there is a middle zone where oxygen is cyclically present and bacterial respiration is "facultatively" aerobic-anaerobic (Tanik et al., 1996; von Sperling and de Lemos Chernicharo, 2005). A facultative oxidation pond receiving sewage typically achieves between 70 to $95 \%$ removal of $\mathrm{BOD}_{5}$ (non-filtered) at a loading rate to the pond of 2.2 to $3.5 \mathrm{~g} \mathrm{BOD}_{5} \mathrm{~m}^{-2} \mathrm{day}^{-1}$ depending on temperature. An effluent quality standard of $30 \mathrm{~g} \mathrm{BOD}_{5} \mathrm{~m}^{-}$

${ }^{3}$ is typically set. Facultative oxidation ponds are directed at reduction of $\mathrm{BOD}_{5}$ and to a lesser extent suspended solids in wastewater (Al-Sa'ed, 2001).

\section{Trickling filter}

A trickling filter (TF) is a wastewater treatment system that is used to reduce $\mathrm{BOD}_{5}$, pathogens, and Nitrogen levels. It is composed of a bed of porous material (rocks, slag, plastic media, or any other medium with a high surface area and permeability). The microorganisms in the wastewater attach themselves to the bed (also known as the filter media), which is covered with bacteria. Wastewater is first distributed over the surface of the media where it flows downward as a thin film over the media surface for aerobic treatment and is then collected at the bottom through an under drain system. The effluent is then settled by gravity to remove biological solids prior to being discharged (Al-Sa'ed, 2001). Like the activated sludge, trickling filter is used in both large and small communities (Kornaros and Lyberatosa, 2006).

\section{Rotating biological contractors}

In Rotating Biological Contractors (RBCs) a number of circular plastic disc are mounted on a central shaft. These discs are submerged and rotated in a tank containing the wastewater to be treated. The microorganisms responsible for treatment become attached to the disc and rotate into and out of the wastewater. The oxygen necessary for the conversion of organic matter adsorbed from the liquid is obtained from the air as a certain area of the disc is rotated out of the liquid. In some designs, air is added to the bottom of the tank to provide oxygen and to rotate the disc when they are provided with air capture cups. It is a very useful system in small communities instead of the conventional secondary treatment, obtaining similar quality in the effluent. RBCs have also been developed for the biological treatment of odours (Smeets et al., 2006). It is flexible enough to undergo fluctuating organic loads, requires little personal attention, cheap to run and does not require too much land. The RBCs have been used in treating winery wastewater and have also been used in the treatment of effluents produced by various industries such as gold mining and domestic sewage treatment (Tawfit et al., 2002).

\section{ACTIVATED SLUDGE SYSTEM}

The activated sludge process is the most widely applied biological wastewater treatment process in the world. The primary objective of the activated sludge system is the removal of soluble biodegradable compounds. It also re- 
moves pathogenic microorganisms from wastewaters. It is capable of achieving equal reductions in soluble substrate in reactors of much smaller volume while producing an effluent relatively free of suspended solids (Mara, 2004; Dewil et al., 2006). The removal efficiency of pathogenic and indicator microorganisms in these wastewater treatment plants vary according to the treatment process type, retention time, other biological flora present in activated sludge, oxygen concentration, $\mathrm{pH}$, temperature and the efficiency in removing suspended solids (Doorn et al., 2006).

\section{Components of the Activated Sludge Treatment Process}

\section{Anaerobic zone}

The anaerobic zone is considered to be one in which both dissolved oxygen and oxidized nitrogen are absent (Eikelboom and Draaijer, 1999). In this zone, sludge from the clarifier flows in jointly with the influent wastewater. It has been reported that for this zone to operate efficiently, oxygen and nitrates must be absent. This is responsible for the release of phosphate (Tanaka et al., 2007).

\section{Primary anoxic zone}

The primary anoxic zone is the main dentrification reactor in the process; it is fed by the effluent from the anaerobic zone and mixed liquor recycled from the aerobic zone. The presence of nitrate or nitrite and absence of oxygen leads to the enrichment of denitrifying bacteria, which reduces nitrate or nitrite to molecular nitrogen. Thus soluble and colloidal biodegradable matters are readily removed in this zone (Metcalf and Eddy, 2003).

\section{Primary aerobic zone}

The primary aerobic zone functions mainly to oxidize organic material in wastewater, ammonia into nitrate and also provides an environment to take up all the phosphate released in the anaerobic zone (Torpak, 2006). For the removal of ammonia, it must first be oxidized to nitrites by nitrifying bacteria such as Nitrosomonas, Nitrosospria and Nitrosolobus spp. Nitrites are then oxidized to nitrates by Nitrobacter, Nirtosospira and Nitrococcus spp. These nitrates are then removed in the primary anoxic zone by denitrifying bacteria. Phosphates uptake is based on the enrichment of the activated sludge with bacteria capable of taking orthophosphate and $E$. coli have been associated with the enhanced pho- sphate removal in activated sludge (Sci-Tech. Encyclopaedia, 2007).

\section{Secondary anoxic zone}

This zone further converts an excess nitrate which was not removed in the zone preceding it into nitrogen. Because of the very slow denitrification rate in this zone, the quantity of nitrate removed is very small. The retention time in the anoxic zone is relatively long because of the lower chemical oxygen demand (Torpak, 2006).

\section{Secondary aerobic zone and clarifier}

This zone removes additional phosphate, which was not removed in the primary aerobic zone. Residual ammonia is also oxidized in this zone. The secondary aerobic zone increases the level of the dissolved oxygen between 2 and $4 \mathrm{mgl}^{-1}$ in the mixed liquor before it enters the clarifier. Aeration should be more to promote phosphate uptake and maintain good aerobic conditions. Phosphorus is retained in the biomass as long as aerobic condition prevails (von Sperling and de Lemos Chernicharo, 2005). This zone prevents the development of anaerobic condition in the clarifier and phosphate release before clarification. In the clarifier, treated wastewater, free of organic matter and dissolved solid is released (Zhou and Smith, 2002; Smeets et al., 2006).

\section{MICROBIOLOGY OF ACTIVATED SLUDGE}

The activated sludge process is a biological method of wastewater treatment that is performed by a variable and mixed community of microorganisms in an aerobic aquatic environment (Jenkins et al., 2003; Richard, 2003). These microorganisms derive energy from carbonaceous organic matter in aerated wastewater for the production of new cells in a process known as synthesis, while simultaneously releasing energy through the conversion of this organic matter into compounds that contain lower energy, such as carbon dioxide and water, in a process called respiration. A variable number of microorganisms in the system also obtain energy by converting ammonia nitrogen to nitrate nitrogen in a process termed nitrification. This consortium of microorganisms, the biological component of the process, is known collectively as activated sludge (Ottoson et al., 2005; Norström, 2005). Bacteria, fungi, protozoa, and rotifers constitute the biological mass, of activated sludge. In addition, some metazoa, such as nematode worms, may be present. Cell makeup depends on both the chemical composition of 
the wastewater and the specific characteristics of the organisms in the biological community. However, the constant agitation in the aeration tanks and sludge recirculation are deterrents to the growth of higher organisms (Lardotter, 2006).

\section{STAGES OF TREATMENT OF WASTEWATER}

\section{Preliminary treatment}

As wastewater enters a treatment facility, it usually undergoes preliminary treatment. This treatment typically involves screening to remove large floating objects, such as rags, cans, bottles and sticks that may clog pumps, small pipes, and down stream processes (USEPA, 2004). Screens are generally placed in a chamber or channel and inclined towards the flow of the wastewater. The inclined screen allows debris to be caught on the upstream surface of the screen, and allows access for manual or mechanical cleaning. Some plants use devices known as comminutors or barminutors which combine the functions of a screen and a grinder. These devices catch and cut or shred the heavy solid and floating materials. In the process, the pulverized matter remaining in the wastewater flow in smaller pieces to be removed later in a primary settling tank (Mara, 2004).

\section{Primary treatment}

Primary treatment is the second step in wastewater treatment and this step helps to separate suspended solids and grease from wastewater (USEPA, 2004). In some treatment plants, primary and secondary stages may be combined into one basic operation (Environment Canada, 2003). At many wastewater treatment facilities, influent passes through preliminary treatment units before primary and secondary treatments begin. With the screening completed and the grit removed, wastewater still contains dissolved organic and inorganic constituents along with suspended solids. The suspended solids consist of minute particles of matter that can be removed from the wastewater with further treatment such as sedimentation or gravity settling, chemical coagulation, or filtration. Pollutants that are dissolved or are very fine and remain suspended in the wastewater are not removed effectively by gravity settling. When the wastewater enters a sedimentation tank, it slows down and the suspended solids gradually sink to the bottom, as primary sludge which can then be removed from the tank by various methods (Environment Canada, 2003).

\section{Secondary treatment}

This is a biological treatment process that removes dis- solved organic matter from wastewater. Ninety percent of the organic matter in wastewater could be removed by this treatment processes. Sewage microorganisms are cultivated and added to the wastewater. The microorganisms absorb organic matter from sewage as their food supply in the process removing such organic matters from circulation (USEPA, 2004). The three most common conventional methods used to achieve secondary treatment are attached growth processes, suspended growth processes and lagoon systems (Upadhyaya et al., 2007). Attached growth processes involve microbial growth on surfaces such as stone or plastic media. Wastewater passes over the media along with air to provide oxygen. Attached growth process units include trickling filter, biotowers and rotating biological contactors. The growth processes are effective at removing biodegradable organic material from the wastewater (Environment Canada, 2003). Suspended growth processes are designed to remove biodegradable organic material and organic nitrogen-containing material by converting ammonia nitrogen to nitrate. In this growth processes the microbial growth is suspended in an aerated water mixture where the air is pumped in, or the water is agitated sufficiently to allow oxygen transfer. Suspended growth process unit include variations of activated sludge, oxidation ditches and sequencing batch reactor (Mbwele et al., 2003). A wastewater lagoon or treatment pond is a scientifically constructed pond, three to five feet deep, that allows sunlight, algae, bacteria and oxygen to interact. Biological and physical treatment processes occur in the lagoon to improve water quality. The quality of water leaving the lagoon, when constructed and operated properly, is considered equivalent to the effluent from a conventional secondary treatment system. Lagoons remove biodegradable organic material and some of the nitrogen from wastewater (Larsdotter et al., 2003).

\section{Advanced or tertiary treatment}

Tertiary treatment is the term applied to additional treatment that is needed to remove suspended and dissolved substances remaining after conventional secondary treatment. This may be accomplished using a variety of physical, chemical or biological treatment processes to remove the target pollutants (Environment Canada, 2003). Tertiary treatment may include: Filtration, Removal of Ammonia and other specific contaminants and Disinfection to destroy pathogens (Hijnen et al., 2006).

\section{Disinfection}

Untreated or inadequately treated wastewaters may contain pathogens. Processes used to kill or deactivate these 
Table 1. Wastewater limit values applicable to discharge of wastewater into a water source according to amended Act of 1956 (South Africa water service Act No 54 of 1956).

\begin{tabular}{|l|c|c|}
\hline \multicolumn{1}{|c|}{ Parameter } & General limit & Special limit \\
\hline Faecal Coliform per 100mL & 0 & 0 \\
Chemical Oxygen Demand $(\mathrm{COD}) \mathrm{mgL}^{-1}$ & 75 & 30 \\
Maximum Temperature $\left({ }^{\circ} \mathrm{C}\right)$ & 35 & 25 \\
Chlorine as free Chlorine $\left(\mathrm{mgL}^{-1}\right)$ & 0.25 & 0 \\
Orthophosphate as Phosphorus $\left(\mathrm{mgL}^{-1}\right)$ & 10 & 1 \\
Fluoride $\left(\mathrm{mgL}^{-1}\right)$ & 1 & 1 \\
Soap, Oil or grease $\left(\mathrm{mgL}^{-1}\right)$ & 2.5 & 2.5 \\
$\mathrm{pH}$ & $5.5-9.5$ & $5.5-7.5$ \\
\hline
\end{tabular}

Source: Veenstra et al. (1997).

harmful organisms are called disinfection. Chlorine is the most widely used disinfectant but ozone and ultraviolet radiation are also frequently used for wastewater effluent disinfection (Hijnen et al., 2006). Chlorine kills microorganisms by destroying cellular materials and can be applied to wastewater as a gas, liquid or in a solid form. However, any free (uncombined) chlorine remaining in the water, even at low concentrations, is highly toxic to beneficial aquatic life (Hijnen et al., 2006). Therefore, removal of even trace amounts of free chlorine by dechlorination is often needed to protect fish and aquatic life. Ozone is also used for disinfection, and it is produced from oxygen exposed to a high voltage current. Ozone is very effective at destroying viruses and bacteria and decomposes back to oxygen rapidly without leaving harmful by-products. The setback in the use of ozone however, is its high energy costs (Hijnen et al., 2004). Ultraviolet (UV) radiation disinfection is a physical treatment process that leaves no chemical traces. Organisms can sometimes repair and reverse the destructive effects of UV when applied at low doses. Furthermore, UV can only be applied on small scale basis (Hoyer, 2004).

\section{REGULATORY STANDARDS FOR WASTEWATER EFFLUENT QUALITY}

Wastewater treatment aims at producing effluent suitable for agricultural or aquacultural reuse (or both), or to produce an effluent that can be safely discharged into inland or coastal waters. Effluent quality requirements often termed effluent quality standards are set by regulatory agencies that are empowered by legislation to make such regulations. These agencies have duties, either explicitly defined in the governing legislation or at any rate implicitly, to set sensible regulations. Unfortunately, in many countries not all such regulations are sensible as they should be (Mara, 2004; von Sperling and de Lemos Chernicharo, 2005). Permits for wastewater treatment systems must be obtained from appropriate authorities (WHO, 2006). In the US for example, if the discharge from a treatment plant enters a stream, a National
Pollutant Discharge Elimination System (NPDES) permit is required. The NPDES permit specifies the maximum allowable level of total suspended solids, biochemical oxygen demand, nutrients and bacteria that can be discharged to a stream as well as the minimum level of dissolved oxygen that must be present in the discharge. The levels specified in the NPDES permit are determined by the condition of the receiving stream. Therefore, NPDES permits are subject to change every 5 years as water quality concerns change throughout (WHO, 2006).

Wastewater poses a significant pollution threat to water-bodies and soil and hence the quality of the effluents must be controlled, especially with regards to the two variables- (i) polluting power (BOD, TOC, suspended solids and COD) and (ii) nutrients (phosphate, nitrate, and ammonium). Toxins are also controlled depending on the industry type, and these would include solvents, heavy metals, phenols, chlorinated compounds and such like (WHO, 2006). In South Africa, municipal wastewater according to the water Act No. 36 of 1998 stipulates limits for certain parameters especially effluent disposal in catchments areas as shown in Table 1. The effluent must not contain any substance capable of producing colour, odour or taste. In South Africa, sewage articulations exist in nearly all urban areas. However, rural areas as well as most semi-urban areas are generally devoid of such facilities (Momba et al., 2006).

\section{EFFECTIVENESS OF WASTEWATER TREATMENT}

The effectiveness of conventional wastewater treatment processes has become limited over the last two decades because of new challenges (Smeets et al., 2006). Zhou and Smith (2002) observed that increased knowledge about the consequences from water pollution and the public desire for better quality water has promoted the implementation of much stricter regulations by expanding the scope of regulated contaminants and lowering their maximum contaminant levels (MCLs). Another factor is the diminishing water resources and rapid population growth and industrial development (USEPA, 2004). Some 
of the key challenges faced by the wastewater treatment sector today include: old and worn-out collection facilities requiring further improvement, repair or replacement to maintain their useful life; the character and quantity of contaminants presenting problems today are far more complex than those that presented challenges in the past; population growth is taxing many existing wastewater treatment systems and creating a need for new plants; farm runoff and increasing urbanization provides additional sources of pollution not controlled by conventional wastewater treatment; and one third of new development is served by decentralized systems (e.g., septic systems) as population migrates further from metropolitan areas (Mara, 2004).

Treatment plants remove varying amounts of contaminants from wastewater; depending on the level of treatment they provide (Environment Canada, 2003). Chlorination, UV irradiation and ozonation are three common disinfection techniques among others that have shown various degree of success in the removal of pathogens from wastewater over the years (EPA, 2002). Recent literature however, points to the inadequacies of these techniques in the removal of some pathogens from wastewater. For example, UV and chemical disinfection with chlorine has been reported to be ineffective against some viruses and bacterial spores, Acanthamoeba, Cryptosporidium and Giardia spp. (Tree et al., 2003; Gomez et al., 2006). Ozone applied at low CT (concentration and contact time) values to limit formation of bromate was also reported to have relatively little effect on the infectivity of the protozoan (oo)cysts (Hijnen et al., 2006). Hoch et al. (1996) reported that heterotrophic bacterial community was not significantly affected by the input of treated sewage, as faecal contamination was readily detected over a comparatively long stretch of 30 $\mathrm{km}$ in the receiving watershed (Danube River, Vienna, Austria) following the point of sewage discharge. Factors that influence microbial sensitivity to disinfection include attachment to surfaces, encapsulation, aggregation and low-nutrient growth (LeChevallier and Au, 2004). WasteActivated Sludge (WAS) processes which are key technologies to treat wastewater have been shown to also have presence of heavy metals in the excess sludge which are difficult to remove by common sludge treatment methods such as aerobic or anaerobic digestion (Dewil et al., 2006). It was opined that the advancement of wastewater treatment technology notwithstanding, treated sewage may still contain some harmful substances irrespective of thoroughness and sophistication of treatment process, albeit in smaller quantities than in raw sewage (Environment Canada, 2003). The authors further reported that in many cases, the concentrations of the remaining pollutants may still be high enough to cause serious environmental damage.

\section{CONSEQUENCES OF INADEQUATE WASTEWATER TREATMENT}

The consequences of discharging untreated or inadequately treated wastewater into the environment are as diverse as they are many. Municipal wastewater can result in increased nutrient levels (eutrophication), often leading to algal blooms; depleted dissolved oxygen, sometimes resulting in fish kills; destruction of aquatic habitats with sedimentation, debris, and increased water flow; and acute and chronic toxicity to aquatic life from chemical contaminants, as well as bioaccumulation and biomagnification of chemicals in the food chain (Kapitain, 1995; Boesch et al., 2001).

The release of untreated or inadequately treated municipal wastewater effluents may put public health at risk from drinking water contaminated with pathogenic bacteria, protozoans (such as Giardia and Cryptosporidium spp.), and several toxic substances (Paillard et al., 2005). The masses are also put at risk from consuming contaminated fish and shellfish and engaging in recreational activities in contaminated waters (Kapitain, 1995). Carcinogenic and endocrine disrupting substances as well as pharmaceuticals can pass through even the most advanced wastewater treatment systems (Heberer, 2002). Endocrine disrupting substances are known to disrupt or mimic naturally occurring hormones and may have an impact on the growth, reproduction, or development of many species of wildlife (Furuichi et al., 2004).

Wastewater pollution also has its socio-economic impacts on the teeming populace. Goodland and Daly (1996) reported that the natural capital is comprised of intact ecosystems and ecosystem services (structurally and functionally). Wastewater pollution negatively affects the ecosystem; with the high rate of wetland destruction, depletion of plant biomass, effects on aquatic wildlife habitat, and the decrease in freshwater access, the ecosystem services provided by these components will continue to degrade (Boesch et al., 2001). The natural capital of the earth is thus depleted where the ecosystem looses its capacity to provide the usual vital services. The main objective therefore of championing the course of a high wastewater effluent standard, is to maintain the natural capital so as to ensure that adequate resources are available for natural benefits (Smith et al., 2005).

\section{MICROBIAL PATHOGENS IN WASTEWATER}

Microbial pathogens which can be potentially present in wastewater can be divided into three separate groups: viruses, bacteria, and the protozoans/helmiths (LeChevallier and $\mathrm{Au}, 2004$ ). 


\section{Viruses}

Viruses are among the most important and potentially most hazardous pathogens in wastewater (Tree et al., 2003). According to Toze (1997), untreated wastewater can contain a range of viruses with their numbers in excess of $10^{3}$ to $10^{4}$ viral particles per litre of wastewater. Viruses are generally more resistant to treatment, more infectious, more difficult to detect in environmental samples such as wastewater and require smaller doses to cause infection than most of the other pathogens (Gomez et al., 2006). The common viruses found in wastewater enter the environment through faecal contamination from infected host or carriers (Leclerc et al., 2000). Most of the commonly detected pathogenic viruses in wastewater are the enteroviruses; they are small, single-stranded RNA viruses and include the poliovirus types 1 and 2. Others are multiple strains of echovirus, enterovirus and coxsackievirus (Tanji et al., 2002). While most members of the general population are susceptible to enteric viral infection, children, the elderly and the immunocompro-mised are the most at risk and have highest infection rate (Toze, 1997).

\section{Bacteria}

Bacteria are the most common of microbial pathogens found in wastewater. A wide range of bacterial pathogens and opportunistic pathogens associated with wastewater are enteric in origin and have been reported in literature (Simpson and Charles, 2000). Gastrointestinal infections are amongst the most common diseases caused by bacterial pathogens in wastewater (LeChevailler and Au, 2004). Wastewater associated infections generally include diarrhoea, dysentery, dysentery-like infections, Leptospira interrogans infections, typhoid, human enteritis, legionellosis, melioidosis, stomach ulcer and cancer (Liang et al., 2006). The contamination of food by water containing known toxin producing organisms such as Staphylococcus aureus, Salmonella spp., E. coli, or Clostridium perferinges can cause outbreaks of food poisoning (often severe and widespread) (Toze, 1997). One of the emerging wastewater bacterial pathogens of grave public health concern in recent times is Listeria monocytogenes otherwise known as invasive Listeria. Several cases of Listeria outbreaks associated with wastewater have been reported around the globe (Paillard et al., 2005).

\section{Protozoa}

Pathogenic protozoa are more prevalent in wastewater than any other environmental source (Toze, 1997).
Pathogenic protozoans associated with wastewater include, Entamoeba histolytica, Giadia intestinalis (formerly Giadia lamblia) and Cryptosporidium parvum, and these organisms have been frequently isolated from wastewater sources with faecal contamination (Caccio et al., 2003; Toze, 1997).

\section{Helminths}

Helminths (nematodes and tapeworms) are common intestinal parasites which, like the enteric protozoan pathogens, are usually transmitted by faecal route in humans (Feenstra et al., 2000). Helminth parasites commonly detected in wastewaters include the round worm (Ascaris lumbricoides), the hook worm (Ascaris duodenale or Nector americanus), the whip worm (Trichuris trichiura) and Strongloides stercolaris the causative agent of strongyloidiasis (Feenstra et al., 2000 ). It has been estimated that approximately $25 \%$ of the world human population is infected with the round worm, A. lumbricoides (WHO, 1989). The prevalence of Ascaris infection is influenced by population density, education standards, sanitation levels, degree of agricultural development, and cultural dietary habits (Smith et al., 2001). The World Health Organisation lists intestinal nematodes to be of greatest health risk in the use of untreated excreta as well as wastewater for agricultural / aquacultural purposes (WHO, 1989). Children under the age of 19 were reported to be the most affected by nematode infection (Feenstra et al., 2000).

\section{MICROBIAL INDICATORS OF WASTEWATER POLLUTION}

The detection, isolation and identification of the many different types of microbial pathogens associated with wastewater would be difficult, time consuming and hugely expensive undertaking if attempted on a regular basis. To avoid the necessity of undertaking such huge ventures, indicator microorganisms are used to determine the relative risk of the possible presence of pathogenic microorganisms in a sample (Ashbolt et al., 2001). To function effectively as indicators, such microorganisms should be a member of the intestinal microflora of warmblooded animals; should be present when pathogens are present, and absent in uncontaminated samples; it should be present in greater numbers than the pathogen(s); should be at least equally resistant as the pathogen to environmental factors and to disinfection in water and wastewater treatment plants; it should not multiply in the environment; it should be detectable by means of easy, rapid, and inexpensive methods and the indicator organism should be non pathogenic (Bitton, 2005). 
Escherichia coli have for a very long time been used as indicators of faecal contamination of water sources, and its growth characteristics and behaviour in the environment is relatively well known (Ashbolt et al., 2001). The ability of $E$ coli to be cultured at elevated temperatures $\left(44.5^{\circ} \mathrm{C}\right)$ has earned them the name of thermotolerant coliforms (TTC) and they have become the mainstay indicator for the water industry (Leclerc et al., 2000). Thermotolerant coliforms are however disadvantaged in that they are more sensitive to environmental changes and treatment processes than a number of more resistant bacterial pathogens and almost all of the viruses, protozoan cyst and helminth eggs (Ashbolt et al., 2001). Another drawback with the use of TTC as an indicator of faecal pollution is that coliform bacteria reside in the gut of many different warm blooded animals. Thus, the detection of TTC in a water source does not necessarily confirm the contamination of that water body with human excrement or the presence of human pathogens. The inappropriateness of faecal coliforms (or TTC) as indicators of human faecal contamination of water sources and of the effectiveness of treatment processes has led to the search for more appropriate indicator microorganisms. A number of bacteria and bacteriophages have been studied for their suitability as indicators.

Clostridium perfringes according to Ferguson et al. (1996) were most useful as indicators of human faecal pollution and the only reliable indicator for the presence of Giardia intestinalis when compared with faecal streptococci and F-RNA bacteriophages. Other potential bacterial indicators for the presence of microbial pathogens in water are the enterococci, bifidobacteria, and bacteroides (Leclerc et al., 2000). Anaerobic indicator bacteria such as bacteroides and bifidobacteria are however difficult to apply as indicators of faecal contamination on a large scale due to handling difficulties associated with these strict anaerobes. This difficulty not withstanding, recent development of DNA probes for polymerase chain reaction (PCR) detection alleviates the requirement of culturing and improves the potentials of anaerobes as indicators of faecal pollution (Kreader, 1995). One of the problems associated with the use of bacteria as indicator for the presence of microbial pathogens in water is the greater resistance of protozoan cysts and viruses to environmental factors and treatment processes (Tree et al., 2003; Hijnen et al., 2006; Gomez et al., 2006).

Viruses in particular are difficult to detect in many water sources due to low numbers, and the difficulty and high cost of culturing (Tanji et al., 2002). To overcome these problems, bacterial viruses (bacteriophages) have been examined for use in faecal pollution and the effectiveness of treatment processes to remove enteric viruses (Ashbolt et al., 2001). The most common bacterioph- age studied is male-specific (F-RNA) bacterio-phage (in particular MS2 and PRD-1) which infect gram negative bacteria containing the $\mathrm{F}^{+}$sex plasmid; somatic coliphages (bacteriophage which infects coliforms); and Bacteroides fragilis specific bacteriophage (Leclerc et al., 2000; Hijnen et al., 2006). Somatic coliphage and F-RNA bacteriophage have been shown to survive but not replicate for long periods in tropical pristine rivers (Hernandez-Delgado and Toranzos, 1995), indicating that they could be useful as indicators in environmental waters. One of the main interests in the use of bacteriophage is their potential for indicating the effect treatment processes have on the survival of pathogenic viruses. Jofre et al. (1995) examined the efficiency of three different water treatment systems to remove bacteriophage from water and found that $B$. fragilis bacteriophages were more resistant to treatment processes than $\mathrm{F}$ specific bacteriophage and somatic coliphage and enteroviruses.

While a number of potential replacement for faecal coliforms have been studied for their possible use, none have been found to be completely suitable. All of the potential indicators studied till date has one or more characteristics which prevent their implementation as replacement for faecal coliforms (Ashbolt et al., 2001; Bitton, 2005). Thus, despite their drawbacks, faecal coliforms still remain the major organisms used to indicate faecal pollution and the effectiveness of treatment processes (Toze, 1997). However, the improvements in the detection of microorganisms by molecular techniques which have occurred in the last 10 years may mean that the use of indicators may no longer be required (Bitton, 2005).

\section{ISOLATION AND DETECTION OF WASTEWATER PATHOGENS}

Methods used to identify and quantify microbial populations in wastewater can be divided into three main groups: culture, immunology and nucleic acid-based.

\section{Culture-based methods}

This method employs selective and/or differential media, which provide a 'presumptive identification' and may be followed by a number of other tests. The tests provide confirmation of the identity of isolates by biochemical, immunological or molecular methods. Abundance is either inferred from the number of colony forming units (CFUs) on culture plates or by Most Probable Number (MPN) dilutions of wastewater samples. For accurate quantification, representative presumptively positive strains must be corroborated by more extensive characterization with biochemical tests or molecular assays. The 
dilution or concentration (by filtration) of samples prior to culture-based enumeration can accommodate a wide dynamic range of wastewater microbial population sizes (Thompson et al., 2004).

One of the disadvantages of culture-based techniques in wastewater sample is that they depend on how reproducibly and quantitatively the target pathogen population will grow on culture media. This is quite limiting as certain pathogens can enter a viable but non-culturable state (VBNC) in response to shifts in environmental conditions possibly complicating interpretation of population dynamics observed in culture-based studies (Besnard et al., 2000). Another disadvantage is that since culture-based techniques inherently rely on growth, they are limited by how fast the target population grows to detectable levels; otherwise they may be outgrown by non-target populations (Toze, 1997). With notable exceptions, most culture-based identification schemes for specific populations are time and labour-intensive, and may require preliminary enrichment or decontamination steps that confound enumeration (Besnard et al., 2000). Despite the above-mentioned limitations of culture-based methods, significant benefits remain. Most notably, the cost of materials needed for culture-based assays in wastewater are relatively cheap and does not require extensive training, and highly specialized materials and equipment. In addition, cultured isolates allow subsequent investigations into the virulence and/or clinical significance of environmental pathogen populations (Thompson et al., 2004).

\section{Immunological methods}

Immunological detection has been used to identify and in some cases, enumerate pathogenic populations in wastewater samples. These methods rely on the inherently high specificity of immune reactions and typically target pathogen-specific antigens such as cell-wall lipopolysaccharides (LPS), membrane and flagellar proteins or toxins. Immuno-assays can be categorized into three main groups: enzyme-linked immunosorbent assay (ELISA), immunofluorescent microscopy, and agglutination assays (Besnard et al., 2000; Bitton, 2005).

There are several notable challenges for the implementation of immunological methods to detection of pathogens in wastewater samples, which contain a large diversity of unknown bacteria. First, the sensitivity of many current methods is not high enough for detection of pathogens at low, environmentally relevant, concentrations. Second, false positive results can be generated by cross-reaction of antibodies with antigens of similar but non-target organisms. This is particularly problematic when polyclonal antibodies are used since these are complex mixtures of antibodies against multiple, mostly uncharacterized cell structures (Thompson et al., 2004; Bitton, 2005). Finally, design and production of specific antibodies generally requires growth of target microorganisms, constraining the applicability of the methods to culturable populations (Bitton, 2005). Despite these limitations, immunological methods have many potential applications for detection of pathogens in wastewater environment (Bitton, 2005).

\section{Nucleic acid based methods}

Advances in molecular biology have revolutionized wastewater microbiology by facilitating the identification of emerging pathogens, the detection of environmental populations, and the discrimination between closely related pathogenic and non-pathogenic bacteria (Persing, 2003). Discrimination of nucleotide variation among genes, whose occurrence is specific to an organism or whose sequence differentiates organisms, is often achieved by nucleic acid hybridization; other methods rely on restriction cutting of the chromosome. Hybridizationbased methods include fluorescence in situ hybridization (FISH) (Loge et al., 1999; Moter and Gobel, 2000; Baudart et al., 2002; Rompre et al., 2002) and filter hybridization (colony and dot-blot hybridization) (Polz and Cavanaugh, 1997; Jiang and Fu, 2001), and the polymerase chain reaction (PCR) (von Wintzingerode et al., 1997; Polz and Cavanaugh, 1998). The PCR couples hybridization of short DNA molecules (primers) to template molecules followed by amplification with a polymerase. Molecular typing methods have used PCR [multi-locus sequence typing (MLST)] or restriction cutting [pulsed field gel electrophoresis (PFGE)] for analyzing genomic signatures (Maiden et al., 1998; van Belkum, 2003). The general principles of hybridization-based, PCR-based, and molecular typing methods have been reviewed in widely available protocol books (Sambrook and Russel, 2001; Persing, 2003).

Nucleic acid-based detection techniques have the advantages of being very target specific, relatively more sensitive and less time consuming. They also have the advantage of detecting viable but non-culturable organisms (Toze, 1997). However, due to their sensitivity, nucleic acid-based methods for detecting wastewater pathogens as in other microorganisms are unable to differentiate between viable and nonviable pathogens (or their resting stages). There is also the issue of false positive reactions due to contamination by extraneous nucleic acids, often through contact with laboratory equipment. Further, there is the need to concentrate large volumes of water in order to get a significant amount of total genomic DNA and this might lead to loss of significant population of the target organism(s) (Toze, 1997). Thus, while the use of nucleic acid-based detec- 
tion techniques show great promise for the detection of pathogens in wastewater, a number of issues need to be resolved before these techniques could be fully deployed as standard detection methods for the wastewater industry.

\section{CONCLUSIONS}

The advancement of wastewater treatment technology notwithstanding, treated sewage may still contain some harmful substances (including microbial pathogens) irrespective of thoroughness and sophistication of the treatment process. There is a wide range of microbial pathogen types which can occur in wastewater, with the type and number present being highly dependent on the socioeconomic conditions and customs of the communities creating the wastewater. In order to propose an efficient way of treating wastewater, there is need to understand the negative environmental impacts posed by the untreated or inadequately treated wastewater entering the nearby ecosystems, especially on the lives that depend on the ecosystem for sustenance. Survival and persistence of such microbial pathogens especially in conventional wastewater treatment facilities is increasingly becoming of interest and is a subject of ongoing investigation in our laboratory.

\section{ACKNOWLEDGEMENT}

We are grateful to the National Research Foundation (NRF) of the Republic of South Africa for financial support (FA Grant Ref. FA2006042400043).

\section{REFERENCES}

Al-Sa'ed R (2001). Process performance optimisation of Al-Bireh wastewater treatment plant. Al-Biereh Municipality, Ramallah. Palestine.

Ashbolt NJ, Grabow WOK, Snozzi M (2001). Indicators of microbial water quality. In WHO Water Quality Guidelines, Standards and Health. Edited by L. Fewtrer and J. Bartram. IWA publishing, London, UK, pp. 289-316.

Baudart J, Coallier J, Laurent P, Prevost M (2002). Rapid and sensitive enumeration of viable diluted cells of members of the family enterobacteriaceae in freshwater and drinking water. Appl. Environ. Microbiol. 68: 5057-5063.

Besnard V, Federighi M, Cappelier JM (2000). Evidence of Viable but Non-Culturable state in Listeria monocytogenes by direct viable count and CTC-DAPI double staining. Food Microbiol. 17: 697-704.

Bitton G (2005). Microbial indicators of faecal contamination: application to microbial source tracking. Report submitted to the Florida Stormwater Association 719 East Park Avenue, Tallahassee, 32301.

Boesch DF, Brinsfield RB, Magnien RE (2002). Chesapeake Bay Eutrophication: Scientific Understanding, Ecosystem Restoration, and Challenges for Agriculture. J. Environ. Qual., 30: 303-320.

Caccio SM, DeGiocome M, Aulicino F, Edoardo P (2003). Giardia cysts in wastewater treatment plants in Italy. Appl. Environ. Microbiol. 69: 3393-3398

Canada's National Environmental Indicator Series (2003). http://www.ec.gc.ca/soer-ree.

Caribbean Environment Programme Technical Report \#40 (1998). Appropriate technology for sewage pollution control in the wider Caribbean Region.

Carter CR, Tyrrel SF, Howsam P (1999). Impact and sustainability of community water supply and sanitation programmes in developing countries. J. Chart. Inst. Water Environ. Manage., 13: 292-296.

Chow VT, Eliason R, Linsley RK (1972). Development and trends in wastewater Engineering. In Wastewater Engineering. McGraw-Hill Book Company. New York, St. Louis, Dusseldorf, Johannesburg, Kuala Lumpur, London, Mexico, Montreal, New Delhi, Panama, Rio de Janeiro, Singapore, Sydney, Toronto. pp. 1-11.

Cooper PF (2001). Historical aspects of wastewater treatment. In Decentralized sanitation and reuse concepts, systems and Implementation. Edited by Lens P, Zeeman G, Lettinga G. IWA Publishing. London (UK). pp. 11-38.

Craggs RJ, Sukias JPS, Tanner CC, Davies-Colley RJ (2003). Performance of an Advanced Pond System Treating Dairy Farm Effluent (Incorporating Preliminary Guidelines). NIWA, Hamilton.

Day D (1996). How Australian social 'policy neglects environments. Austr. J. Soil Water. Conserv. 9: 3-9.

Dewil R, Baeyens J, Neyens E (2006). Reducing the heavy metal content of sewage sludge by advance sludge treatment methods. Environ. Engr. Sci. 23: 994-999.

Doorn MRJ, Towprayoon S, Maria S, Vieira M, Irving W, Palmer C, Pipatti, R, Wang C (2006). Wastewater treatment and discharge. In 2006 IPCC Guidelines for National Greenhouse Gas Inventories volume 5. (Waste). WMO, UNEP. pp. 6: 1-6, 28.

Eikelboom DH, Draaijer A (1999). Activated sludge information system (ASIS). http://www.asissludge.com.

Elimelech $M$ (2006). The global challenge for adequate and safe water. J. Water. Supp.: Res. Technol.-AQUA 55: 3-10.

Environmental Protection Agency (EPA), Victoria (2002). Guidelines for Environmental Management: disinfection of treated wastewater. Publication 730 Victoria, Australia.

Feenstra S, Hussain R, van der Hoek W (2000). Health risk of irrigation with untreated urban wastewater in the Southern Punjab, Pakistan. International Water Management Institute (IWMI) report No. 107.

Ferguson CM, Coote BG, Ashbolt NJ, Stevenson IM (1996). Relationships between indicators, pathogens and water quality in an estuarine system. Water. Res. 30: 2045-2054.

Furuichi T, Kannan K, Giesy JP, Masunaga S (2004). Contribution of known endocrine disrupting substances to the estogenic activity in Tama River water samples from Japan using instrumental analysis and in vitro reporter gene assay. Water Res. 38: 4491-4501.

George N, Andrew L (2003). Control of filamentous organisms in food processing wastewater treatment by intermittent aeration and selectors, J. Chem. Technol. Biotechnol. 78: 420-430.

Gomez M, de la Rua A, Garralon G, Plaza F, Hontoria E, Gomez MA (2006). Urban wastewater disinfection by filteration technologies. Desalin., 190:16-28.

Goodland R, Daly H (1996). Environmental Sustainability: Universal and Non-Negotiable. Ecol. Appl. 6(4): 1002-017.

Heberer T (2002). Occurrence, fate, and removal of pharmaceutical residues in the aquatic environment: a review of recent research data. Toxicol. Lett. 131: 5-17.

Hernandez-Delgado EA, Toranzos GA (1995). In situ replication studies of somatic and male-specific coliphages in a tropical pristine river. Water Sci. Technol. 31: 47-250.

Hijnen WAM, Beerendonk EF, Medema GJ (2006). Inactivation of UV radiation for viruses, bacteria, and protozoan (0o)cysts in water: a review. Water Res. 40: 3-22.

Hijnen WAM, van der Veer AJ, Beerendonk EF, Medema GJ (2004). Increased resistance of environmental anaerobic spores to inactivation by UV. Water Sci. Technol. Water Suppl. 4(2): 54-61. 
Hoch B, Berger B, Kavka G, Herndi GJ (1996). Influence of wastewater treatment on the microbial ecology of large, temperate river systemDanube River. Hydrobiol. 321: 205-218.

Hoyer O (2004). Water disinfection with UV radiation-requirements and realization. In Proceedings of the European Conference UV Karlsruhe, UV radiation. Efects and technologies, 22-24 September 2003, Karlsruhe.

Jenkins D, Richard MG, Daigger GT (2003). Manual on the Causes and Control of Activated Sludge Bulking and Foaming. Lewis Publishers, Boca Raton, Florida.

Jiang SC, Fu W (2001). Seasonal abundance and distribution of Vibrio cholerae in coastal waters quantified by a 16S-23S intergenic spacer probe. Microb. Ecol., 42: 540-548.

Jofre J, Olle E, Ribas F, Vidal A, Lucena F (1995). Potential usefulness of bacteriophages that infects Bacteroides fragilis as model organisms for monitoring virus removal in wastewater treatment plants. Appl. Environ. Microbiol. 61: 3227-3231.

Kapitain J (1995). Ontario's sewage treatment plants and their effect on the environment. Environmental Probe Publications. www.environmentprobe.org/enviroprobe.

Kornaros M, Lyberatosa G (2006). Biological treatment of wastewaters from a dye manufacturing company using a trickling filter. J. Hazard. Mater., 136(1): 95-102.

Kreader CA (1995). Design and evaluation of Bacteroides DNA probes for the specific detection of human faecal pollution. Appl. Environ. Microbiol. 62: 3259-3264.

Larsdotter K (2006). Wastewater treatment with microalgae - a literature review. Vatten., p. 62.

Larsdotter K, Söderbäck E, Dalhammar G (2003). Phosphorus removal from wastewater by microalgae in a greenhouse in Sweden. In Proceedings at the IWA conference on Environmental biotechnology, December 2003, Malaysia.

LeChevallier MW, Au K (2004). Inactivation (disinfection) processes. In Water Treatment and Pathogen Control. IWA Publishing., pp. 41-65.

Leclerc H, Edberg S, Pierza V, Delattre JM (2000). Bacteriophages as indicators of enteric viruses and public health risk in groundwaters. J. Appl. Microbiol. 88: 5-21.

Liang JL, Dziuban EJ, Craun GF, Hill V, Moore MR, Gelting RJ, Calderon RL, Beach MJ, Roy SL (2006). Surveillance for waterborne disease and outbreaks associated with drinking water and water not intended for drinking. CDC/ MMWR 55(SS12): 31-58.

Loge FJ, Emerick RD, Thompson, D.E., Nelson, D.C., Darby, J.L., 1999. Development of a fluorescent 16s rRNA oligonucleotide probe specific to the family Enterobacteriaceae. Water Env. Res. 71: 75-83.

Maiden MC, Bygraves JA, Feil E, Morelli G, Russell JE, Urwin R, Zhang Q, Zhou J, Zurth K, Caugant DA (1998). Multilocus sequence typing: a portable approach to the identification of clones within populations of pathogenic microorganisms. Proc. Natl. Acad. Sci., 95: 3140-3145.

Mara DD (2004). Domestic Wastewater Treatment in Developing Countries Earthscan Publications, London.

Mbwele L, Rubindamayugi M, Kivaisi A, Dalhammar G (2003). Performance of a small wastewater stabilisation pond system in tropical climate in Dar es Salaam, Tanzania. Water Sci. Technol. 48(11-12): 187-191.

Metcalf and Eddy (2003). Wastewater Engineering: Treatment and Reuse. In: Tchobanoglous G, Burton FL, Stensel HD (Eds.), Tata McGraw-Hill Publishing Company Limited, fourth ed., New Delhi, India.

Momba MNB, Osode AN, Sibewu M (2006). The impact of inadequate wastewater treatment on the receiving water bodies case study: Buffalo City and Nkonkonbe Municipalities of the Eastern Cape Province. Water SA., 32: 687-692.

Moter A, Gobel UB (2000). Fluorescence in situ hybridization (FISH) for direct visualization of microorganisms. J. Microbiol. Method 41: 85112.

Norström A (2005). A comparative study of six hydroponic wastewater treatment plants. Vatten. 61(2): 95-104.

Ottoson J, Norström A, Dalhammar G (2005). Removal of microorga- nisms in a small-scale hydroponics wastewater treatment system. Lett. Appl. Microbiol. 40(6): 443-447.

Paillard D, Dubois V, Thiebaut R, Nathier F, Hoogland E, Caumette P, Quentine C (2005). Occurrence of Listeria spp. in effluents of French urban wastewater treatment plants. Appl. Environ. Microbiol. 71(11): 7562-7566.

Persing DH, Tenover FC, Versalovic J, Tang YW, Unger ER, Relman DA White TJE (2003). Molecular Microbiology: Diagnostic Principles and Practice. Am. Soc. Microbiol., Washington, DC, pp. 748.

Polz MF, Cavanaugh CM (1997). A simple method for quantification of uncultured microorganisms in the environment based on in vitro transcription of 16S rRNA. Appl. Environ. Microbiol. 63: 1028-1033.

Polz MF, Cavanaugh CM (1998). Bias in template-to-product ratios in multitemplate PCR. Appl. Environ. Microbiol. 64: 3724-3730.

Richard M (2003). Activated Sludge Micribiology Problems and their Control. In Proceedings of the $20^{\text {th }}$ Annual USEPA National Operator Trainers Conference, 8 June, 2003, Buffalo, New York.

Rompre A, Servais P, Baudart J, de-Roubin MR, Laurent P (2002). Detection and enumeration of coliforms in drinking water: current methods and emerging approaches. J. Microbiol. Methods 49: 31-54.

Sambrook J, Russel DW (2001). Molecular Cloning: A Laboratory Manual. Cold Spring Harbor Laboratory Press, New York.

Sci-Tech.Encyclopaedia (2007). http://www.answers.com/topic/sewagetreatment.

Sharman R (2004). Process Control II, Water and Wastewater Technology, LBCC. Available from: http://www.lbcc.cc.or.us/process2/tricklingfilter/tricklingsum.html.

Simpson E, Charles K (2000). The health threat posed to surrounding community by effluent discharged from rural hospital sewage treatment plants. In Proceeding of the Water Institute of Southern Africa Conference, 28 May - 1 June, Sun City, South Africa.

Smeets P, Rietveld L, Hijnen W, Medema G, Stenström T (2006). Efficacy of water treatment processes. In MICRORISK (Microbiological risk assessment: a scientific basis for managing drinking water safety from source to tap) April, 2006. http://217.77.141.80/clueadeau/microrisk/uploads/microrisk efficacy of water treatment processes.

Smith DM, Roebeling PC, Webster AJ, Kragt M, Bohnet I, Zull A (2005). Assessment of the Socio-Economic Impacts of Management Options for Improving Water Quality in Douglas Shire. CSIRO Sustainable Ecosystems. Alice Springs, Atherton, Brisbane, Canberra, Darwin, Perth, Toowoomba, Townsville.

Smith HM, Dekaminsky RG, Niwas S, Soto RJ, Jolly PE (2001). Prevalence and intensity of infections of Ascaris lumbricoides and Trichuris trichura and associated partner-demographic variables in four rural Hondorian Communities. Memór. do Instit. Oswaldo Cruz., 96: 303-314.

Tajrishi M, Abrishamchi A (2005). Integrated Approach to Water and Wastewater Management for Tehran, Iran, "Water Conservation, Reuse, and Recycling: Proceedings of an Iranian-American Workshop (2005)", the National Academies Press, Washington, D.C.

Tanakaa Y, Yatagaib A, Masujimac H, Wakia M, Yokoyama H (2007). Autotrophic denitrification and chemical phosphate removal of agroindustrial wastewater by filtration with granular medium. Bioresour. Technol. 98(4): 787-791.

Tanik A, Sarikaya HZ, Eroglu V, Orhon D, Ozturk I (1996). Potentail for reuse of treated effluent in Instanbul. Water Sci. Technol., 33: 107133.

Tanji Y, Mizoguchi K, Yoichi M, Morita M, Hori K, Unno H (2002). Fate of coliphage in wastewater treatment process. J. Biosci. Bioeng. 94: 172-174.

Tawfit A, Klapwijk B, El-Gohary F, Lettinga G (2002). Treatment of anaerobically pre-treated domestic sewage by rotating biological contractor, Water Res. 36: 147-155.

Tchobanoglous G, Angelakis AN (1996). Technologies for wastewater treatment appropriate for reuse: Potentail for applications in Greece. Water Sci. Technol. 33: 15-24.

The People's Daily, Friday, November 30, (2001), Beijing. World Bank 
supports China's wastewater treatment.

Thompson JR, Randa MA, Marcelino LA, Tomita-Mitchell A, Lim EL, Polz MF (2004). Diversity and Dynamics of a North Atlantic Coastal Vibrio Community. Appl. Env. Microbiol. 70: 4103-4110.

$\begin{array}{llll}\text { Torpak } & \text { (2006). } & \text { Activated } & \end{array}$ http://web.deu.edu.tr/atiksu/toprak/ani406.html.

Toze S (1997). Microbial pathogens in wastewater. CSIRO Land and Water Technical report $1 / 97$.

Tree JA, Adams MR, Lees DN (2003). Chlorination of indicator bacteria and viruses in primary sewage effluent. Appl. Environ. Microbiol. 69:2038-2043.

United Nations Commission on Sustainable Development 1997. Comprehensive assessment of the fresh water resources of the world: A report of the Secretary-General. www.un.org/dpcsd/dsd/freshwat.htm.

United States Environmental Protection Agency (U.S. EPA) (2004) Primer for Municipal Wastewater treatment systems. U.S. EPA, Washington DC.

Upadhyay AR, Mishra VK, Pandey SK, Tripathi BD (2007). Biofiltration of secondary treated municipal wastewater in tropical city. Ecol. Eng., 30: 9-15.

Van Belkum A (2003). High-throughput epidemiologic typing in clinical microbiology. Clin. Microbiol. Infect. 9: 86-100.

Veenstra S, Alaerts GJ, Bijlsma M (1997). Technology Selection: Water pollution Control. E and FN Spon, London.
Vijayaraghavan K, Ahmada D, Mohd AZ (2007). Aerobic treatment of palm oil mill effluent. J. Environ. Manage., 82: 24-31.

von Sperling $M$, de Lemos Chernicharo CA (2005). Biological Wastewater Treatment in Warm Climate Regions. IWA Publishing, London.

vonWintzingerode F, Gobel UB, Stackebrandt E (1997). Determination of microbial diversity in environmental samples: Pitfalls of PCR-based rRNA analysis. FEMS Microbiol. Rev., 21: 213-229.

Welch EB (1992). Ecological effects of wastewater: applied limnology and pollutant effects. Chapman and Hall, New York.

World Health Organization (1998). Cholera in 1997. Wkly Epidemiol. Rec., 73: 201-208.

World Health Organization (2006). Guidelines for the Safe Use of Wastewater, Excreta and Greywater: Wastewater Use in Agriculture. World Health Organization, Geneva.

Zhou H, Smith DW (2002). Advanced technologies in water and wastewater treatment. J. Environ. Eng. Sci., 1: 247-264. 